\title{
Employer Branding and its Role in Effective Recruitment
}

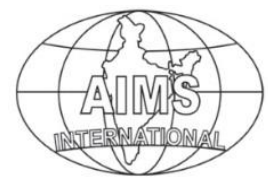

DOI: $10.26573 / 2020.14 .2 .2$

Volume 14, Number 2

May 2020, pp. 89-100

\author{
Puja Kumari \\ Mili Dutta \\ BIT, Lalpur \\ (pujakumari.0207@gmail.com) \\ (milidutta@bitmesra.ac.in) \\ Manju Bhagat \\ BIT, Mesra \\ (mbhagat@bitmesra.ac.in)
}

The concept of employer branding focuses on the development of a positive image for the firm. The main purpose of this study is to investigate five-value proposition of employee attractiveness. Data collection has been done using questionnaire and analysis has been done through SPSS. The analysis suggests that value proposition such as interest value, social value, application value, development value and economic value is related to the creation of employer branding. Findings also suggest that social value is very crucial value for employees and for hiring a new employee in the organization. While searching the job more preference is given to the employer-employee relations and good relations with colleague so that they can feel sense of belongingness with the organization. Economic and functional benefits are also important pillars in creating employer branding. Thus, the various value propositions play a significant role in attracting potential candidates and ensuring an effective hiring. However, there is still no specific consistent strategy to attract potential talent. There has been little focus given on recruiter's engagement using various social media platforms.

Keywords: Value Proposition, Potential Candidate, Hiring, Employer Branding, Employee Attractiveness

\section{Introduction}

Every organization faces crucial challenges in order to survive in the global competitive market, to encounter growth, sustain itself (Mosley, 2007) and gain competitive advantages (Lievens \& Highhouse, 2003; Sivertzen, et al., 2013). Efficient Human capital is the basic need for the survival of the organization; therefore, recruitment of right and competent candidate becomes a necessary element for the organization (Wright, McMahan \& McWilliams, 1994). Along with this aspect, the current trend also demands a far more comprehensive and strategic perspective to recruit, utilize and retain valuable human resources (Guthridge et al. 2008). The importance to attract, recruit and retain talents has been acknowledged by every organization as they face the scarcity of potential employee in the labor market (Chhabra \& Sharma, 2014). Companies are concerned about their employee's opinion, loyalty, retention and their perception towards the company, so they find what strategy should be made to attract the potential employees (Dabirian et al., 2016). In a global market, employer brand and corporate reputation are imperative 
factor for attracting the best talent (Cappelli, 2001). Employer attractiveness is defined as, "the envisioned benefits that a potential employee sees in working for a specific organization" and the package of benefits in which potential employees perceive from his future job (Berthon, P., Ewing, M. \& Hah, L.L., 2005). Although, how this attractiveness generated in the mind of the potential employee and influences them to apply for a job; is still a matter of discussion. Previous researches have indicated that potential employee compare their own needs, personality and value with the organization's image (Backhaus and Tikoo, 2004). When employee's desires match with the organization's image, the organization becomes attractive to them (Schneider, 1987; Cable \& Judge, 1996; Backhaus \& Tikoo, 2004). Strong brand image of a company has benefits such as hiring of employee at low cost, enhance employee relation, hire best talent in lower pay scale and also helpful in improving employer- employee relations (Riston, 2002). "Branding" is the commitment between an organization and its potential or existing customers which has to be understood and delivered by the organization (Foster, Punjaisri \& Cheng, 2010). Employer branding is a tool which is used to enhance employer attractiveness and corporate reputation (Sivertzen et al., 2013). It focuses on the outside the organization where there could be chances to convert potential employee to become the part of the organization (Foster et al., 2010).

Previous literature reviews state the significant impact of employer branding on retention of employees (Ambler \& Barrow, 1996; Armstrong, 2007; Backhaus \& Tikoo, 2004; Chhabra \& Sharma, 2014). But a few research works have been conducted to find the role of employer branding dimensions for attraction of candidates. In this study we have tried to find out the employer attractiveness depends upon which of the major factors of employer branding in recruitment influence them to apply for a job.

The main purpose of this paper is to find out role of different value proposition of employer branding dimensions on job seekers to attract and influence them to apply for a job. Organization image perception and attractiveness can influence the job seekers to apply for the job. The study outlines the key factors or value propositions of employer branding for the organizational attractiveness. The study will also help the managers to make the organization more attractive and eye-catching for the job seekers. The core objective of the study is to determine which value proposition of employer branding affects employee attraction.

The objectives of our study are

\section{Objectives of the Study}

1. To study the concept of employer branding.

2. To study the role/significance of employer branding in recruitment.

3. To identify the factors influencing employer branding.

4. To determine the value propositions of employer branding which affects employee attractiveness.

\section{Concept Related to Employer Branding}

Branding is a very well-known area of marketing, but it is new and is at the nascent stage in the Human resource management (Edwards, 2010). The significance of 
brand image in product market is well known, but it also plays a key role in recruitment process (Sivertzen, Nilsen \& Olafsen, 2013). In the organization 'employees' are the most important resource and 'brand' is an asset for the company (Ambler \& Barrow, 1996). Considering other side of view, the employer creates his/her image as a brand which communicates loyalty, trust, positive attitudes towards the potential employee.

The concept of employment brand very specifically pointed out by Swystun (2007) who argued "a brand is a mixture of attributes, tangible and intangible, symbolized in a trademark, which if managed properly, creates value and influence" (p.14). In this definition, researcher agrees that branding is essential to create organization's image positively. Similar to the concept of 'branding' in marketing, 'employment brand' also provides the uniqueness of the product and gaining distinct employment experience (Edwards, 2010). It is assumed that when organizations clearly interpret the employment experience, it helps in creation of brand perception towards the potential recruits and influences them to apply for job (Edwards, 2010). The employment experience is organization specific; in this regard Backhaus and Tikoo (2004) argue, employer branding "suggests differentiation of a firm's characteristics as an employer from those of its competitors, the employment brand highlights the unique aspects of the firm's employment offerings or environment" ( $p$. 502). In this regard, American Marketing Association (1960) said that a 'brand' is a means to differentiate from the competitors, and it gives competitive advantage to the organization (van Reil \& Balmer, 1997). The image of employer brand indicates the nature of employment, career opportunity, challenges and its unique features, which distinguish it from competitors (Arachchige \& Robertson, 2011).

The term 'employer branding' does not refer the short-term recruitment strategy but is focused on long term strategy, having innovation (Srivastava \& Bhatnagpur, 2010) and awareness and creation of perception of different stakeholders regarding the firm (Sullivan, 2004). Brands create a psychological impact on people as they tend to associate the brands mentally as well as emotionally (Brown, 1992; Kapferer, 2004). The employer branding concept is mostly applicable in high value-added business or services where salary is high and number of working employees is few (Ambler \& Barrow, 1996). Backhaus and Tikoo have (2004) defined employer branding as "the process of building an identifiable and unique employer identity".

Ambler \& Barrow (1996) proposed three dimensions of employer branding namely: functional, economical and psychological. Functional branding is defined as development or engagement of some useful activity (Ambler \& barrow, 1996, p.187). Economic benefit is the sum up as 'material or monetary reward' which signifies not only the price but also the additional things involved in the product. Psychological benefits are intangible in nature and constitute of feelings such as belongingness, purpose and satisfaction (Ambler \& Barrow, 1996).

\subsection{Role/ Significance of Employer Branding in Recruitment}

Employer branding is a sum total of psychological, economic, and functional benefits provided by employment and identified by the employer (Ambler \& Barrow, 1996; Lievens \& Highhouse, 2003). Employer branding creates a psychological impact on prospective employee as an ideal place to work (Lloyd, 2002). Job-seekers perception towards a brand is closely related to the company's reputation (Micik \& 
Micudova, 2018), which most likely is the reflection of brand (Fombrun, 1996). Several studies have also suggested that there is a relationship between image of the organization and attraction of quality job applicants (Fombrun, 1996; Cable \& Turban, 2001). Many researches support the findings that reputation and brand image of organization play a significant role in recruitment process (Berthon et al, 2005; Lievens et al., 2007; Xie, Bagozzi \& Meland, 2015).

Employer branding becomes an 'umbrella programme' to give a definite structure to the previous HR policies and practices (Edwards, 2010). Employer branding also targets current and potential employees.

\subsection{Value Proposition of Employer Branding}

Value proposition is considered as a 'backbone of employer branding', as it develops a clear vision about organization and also significantly helps in employee attraction and retention (Sengupta et al., 2015). In order to attract a potential candidate, , after designing external marketing strategy, a successful employer branding strategy first identifies and develops their value propositions consisting of a combination of several types of offerings (Backhaus \& Tikoo, 2004).

The Value proposition of employer branding is measured through five criteria namely; social value, interest value, economic value, development value and application value (Sivertzen, 2013). Social value can be defined as "It calculates the mark of appeal of an organization or a company providing a work environment with good and welcoming team spirit and decent respectable relations among co-workers (Hadi \& Ahmad, 2018). Social value is the sum of the attributes such as fun, happiness, stress upon good employer and employee relationships as well as collegial relation (Berthon et al., 2005). Social value at work is an emotional attachment (Dabirian et al., 2016) and feeling of belongingness from their working place (Sivertzen, 2013). Interest value is related to innovation and development of interest in performing the task to meet the challenges (Sivertzen, 2013) and "It assesses the degree of appeal of an employer who is responsible for providing a work situation with innovation and creativeness opportunities" (Hadi \& Ahmad, 2018). Interest value is the extent to which job-seekers are attracted towards the employer for novel work practices, implication of creativity and innovation in product and services (Berthon et al., 2005). "Economic value estimates the amount of attraction of an employer providing a worthy remuneration and profits" (Hadi \& Ahmad, 2018). Economic value accounts for all types of monetary benefits offer by the firm to their employees which includes salary, compensation package, job security and scope for promotion (Berthon et al., 2005; Dabirian, 2016). Development value refers to the acknowledgement of employees' performance and provides benefits for professional development and future career growth (Dabirian, 2016). It assesses the extent to which an individual is attracted towards the employer that provides confidence, recognition, and career-enhancement. Hadi and Ahmad (2018) defined development value as "It is an attribute that estimates the degree of attractiveness of an employer providing career development". Further, their study found that there is a positive relation between development value with employee retention, but not in case of application value, interest value, and work life balance.

Finally, application value signifies the relevance of work with the knowledge and skills. It makes the work meaningful and determines the degree of attraction towards 
the establishment providing a platform to apply the knowledge (Hadi and Ahmad, 2018). It is an extent to which job-seekers are attracted towards the employer and their learning experience for the benefits of society (Berthon et al., 2005).

Apart from this five-value proposition, Dabirian et al. (2016) added two value propositions which are management value and work life balance. Management value focuses on employer-employee relations not with the company. A proper work life balance facilitates the people to work in the harmony at work place and also maintain personal life with friends, parents or club members without any conflict (Hadi \& Ahmad, 2018). Other important values added in employer branding are diversity value and psychological value (Hadi \& Ahmad, 2018).

\section{Research Methodology}

The sample size of the study was 205 consisting of job seekers- fresh graduates or final year students and employees who are actively searching for the better opportunities outside the organization. Hence judgmental sampling has been used in collecting the responses. The students who were selected from the final year of MBA were less than 5 months away from completing their post-graduate degrees and entering in the organization. On the other hand, employees were both full-time and part time and their education level ranges from graduate, post-graduate to M.Phil. / Ph.D. In addition, they were working for the past six months to several years as a part-time or full-time in the organization.

Before the selection of the population of the study and sample size determination, a total of three focus groups discussion were conducted. The participants were finalyear MBA students of different colleges and full time and part-time employees. The purpose of the focus group discussion was to identify the items for employer branding dimensions of the attractiveness construct. For this study, researcher outlined twenty-four items, however, after focus-group discussion there were total fourteen value propositions were identified. These items were rated from 'never' (least preferred) to 'always' (most preferred). For this research, survey method is opted and questionnaire is designed to collect demographic details of the respondents and their opinion related to employee attraction and employer branding. A total of twenty-three questions were designed in which, part-A of the questionnaire contained their name, gender, education level, experience, about their interest and choices. Part-B of the questions was designed in a five-point Likert scale (from 1-Never to 5Always) to measure the outcome value. While designing the questionnaire the various variables taken in consideration are interest value, social value, application value, development value and economic value. The statistical analysis was done using SPSS 20.0.

\section{Data Analysis and Results}

- The sample size of employees was 205, with a mean age of 26.01. The demographic statics show that $61 \%$ males and $39 \%$ females participated in this survey. The details of age group are: $20-25$ was $52.7 \%, 25-30$ was $11.7 \%$, 30-35 was $24.9 \%$ and above 35 was $10.7 \%$. In this survey the following categories were noted: $42.4 \%$ final year students, $5.9 \%$ pass-out students, $47.8 \%$ full-time employee and $3.9 \%$ part-time employee. The educational qualifications of 
respondents as observed are: $33.7 \%$ were graduate, $60.5 \%$ were post-graduate, $4.9 \%$ were M.Phil./PhD and $1 \%$ were others. The work experience of respondents shows that $54.1 \%$ respondents had $1-5$ years of experience, $23.9 \%$ of participants had 3-6 years, 7.3\% of participants had 6-9 years of experience and $14.6 \%$ had above 9 years of work experience.

- In this survey, a question was asked to working employee that are they working in their dream company. The response was (exclamatory), 78\% said 'No', whereas $23.4 \%$ said 'yes' and $38.5 \%$ of the participants haven't decided yet. Among these responses, a majority of respondents were not working in their ideal company. This response left the area of further research that why they are not in their dream organization.

- $35.6 \%$ respondent said they usually attracted to apply for a job due to company's brand position, $20 \%$ people influenced due to the others opinion, $15.1 \%$ due to company's rating given by the agency, $13.7 \%$ due to company's vision and mission and significantly $15.6 \%$ said that other factors about the company attract them to apply for a job.

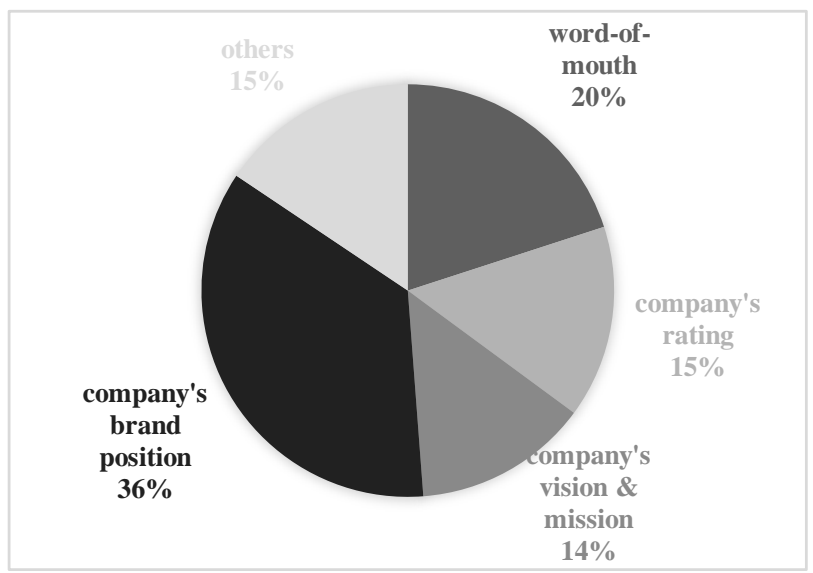

Figure 1 Major Factors Influencing the Job-Seeker to Apply

- While searching and applying for a job 63.9\% respondent looked for career growth opportunity, $19.5 \%$ working environment, $7.3 \%$ company's offerings, $6.3 \%$ employer-employee relations and $2.9 \%$ saw other factors. It could be said that now-a-days career growth opportunity in a company plays a crucial role in applying for a job.

\subsection{Exploratory Factor Analysis (EFA)}

Exploratory factor analysis (EFA) is a statistical method used to find the underlying structure of a relatively large set of variables. Before extraction of the construct, there should be some test was performed to measure the adequacy of the sample and the suitability of data for factor analysis (Burton \& Mazerolle, 2011). Cronbach alpha for the items was 0.786 . The adequacy of sample size of the data was checked by KMO and Bartlett's Test which suggests minimum KMO value should be 0.5 , 
$0.50-0.59$ is miserable, $0.60-0.69$ is mediocre, $0.70-0.79$ is middling, $0.80-0.89$ is meritorious and 0.90 to 1.00 marvelous (Kaiser, 1974; Cerny \& Kaiser, 1977) and the values between 0.5 and 0.7 are rated as average, 0.7 and 0.8 are good, 0.8 and 0.9 are very good and the values 0.9 and above are excellent as recommended by Hadi et al. 2016. Our result of $\mathrm{KMO}$ is 0.834 , which indicates that the data is fit for factor analysis. Bartlett's test of Sphericity results chi-square output checks the suitability (Tabachnick \& Fidell, 2001) for factor analysis and it must be significant $(\mathrm{p}<0.5)$.

Table 1 KMO \& Bartlett's Test of Sphericity

\begin{tabular}{|l|c|}
\hline \multicolumn{2}{|c|}{ KMO and Bartlett's Test } \\
\hline Kaiser-Meyer-Olkin Measure of Sampling Adequacy. & 0.834 \\
\hline Bartlett's Test of Sphericity Approx. Chi-Square & 805.777 \\
\hline Df & 91 \\
\hline Sig. & .000 \\
\hline
\end{tabular}

The data collected through questionnaire was processed in SPSS 20. Principal Component Analysis (PCA) method used along with Direct Oblimin rotation extracted all the factors having Eigen value greater than one $(>1)$. The results were reported in Table 2, in form of pattern matrix which summarizes the component value greater than 0.4 . One of the scale items about the opportunity to learn new things, had the correlated value below 0.4 , hence, has been dropped to reduce the error.

\subsection{Discussion on Finding}

In this study, the first value proposition i.e. Social value assesses the most important variable related to the working environment such as enjoyment, relation with employer and colleague. 'Economic value' offers the potential employee to attract. According to the study, good salary, promotional opportunities and a good compensation package are important for an applicant. 'Interest value' assesses the extent to which the potential employee attracted to the components like enjoyment at work, appreciation, significance of his work. 'Development value' offers to the potential employee career-enhancing opportunity, satisfaction of his work and appreciation. Lastly, 'Application value' offers to learn a new thing, feeling of belongingness with the working environment.

For the study, literature suggests five-value proposition of employer branding (Sivertzen, 2013; Berthon et al., 2005) however, this structure shows the three dimensions of employer branding (psychological, functional \& operational) which was proposed by Ambler \& Barrow (1996). Further, after analyzing the data, our study suggests three factors (or value propositions) of employer branding. These are categorized as social and interest value representing the 'psychological benefits' (Ambler \& Barrow, 1996), development and application value representing the 'functional benefits' (Ambler \& Barrow, 1996) and economic representing the 'operational benefits (Ambler \& Barrow, 1996). 
Table 2 Pattern Matrix

\begin{tabular}{|c|c|c|c|c|}
\hline Q. & Items on Questionnaire & \multicolumn{3}{|c|}{ Component } \\
\hline & & 1 & 2 & 3 \\
\hline $\begin{array}{l}21 . \\
22 . \\
23 . \\
20 . \\
19 .\end{array}$ & $\begin{array}{l}\text { A. Social \& interest } \\
\text { Do you feel a sense of belongingness in the firm? } \\
\text { Do you get enough support from your boss? } \\
\text { Do you get enough support from colleagues at work place? } \\
\text { Are you satisfied at your workplace? } \\
\text { Do you enjoy doing your work }\end{array}$ & $\begin{array}{l}0.77 \\
0.76 \\
0.72 \\
0.72 \\
0.58\end{array}$ & & \\
\hline $\begin{array}{l}11 . \\
10 . \\
12 .\end{array}$ & $\begin{array}{l}\text { B. Economic Value } \\
\text { Are non-monetary benefits most important } \\
\text { Are monetary benefits (salary+ incentives) are most important } \\
\text { Do you look for Career enhancing opportunities? }\end{array}$ & & $\begin{array}{l}0.69 \\
0.58 \\
0.43\end{array}$ & \\
\hline $\begin{array}{l}15 . \\
14 . \\
13 . \\
16 . \\
17 .\end{array}$ & $\begin{array}{l}\text { C. Application \& Development Values } \\
\text { Do you look for getting new things to work? } \\
\text { Do you look for appreciation of new ideas? } \\
\text { Are Social security benefits being most important? } \\
\text { Do you look for fair decision-making policy? } \\
\text { Do you look for opportunities to Participate in decision-making } \\
\text { process in the organization? }\end{array}$ & & & $\begin{array}{l}0.82 \\
0.77 \\
0.69 \\
0.50 \\
0.43\end{array}$ \\
\hline
\end{tabular}

For a job seeker all these elements play a significant role. There is no consistent strategy which can help the recruiters to attract the potential candidates. Social media is gaining significance and companies are using this platform but still one cannot predict a single way out to attract talent. One need to take into consideration every aspect psychological factor like satisfaction at workplace, economic benefits, growth opportunity etc. as each of them plays a pivotal role. People also want social security at work like insurance schemes, provident fund and gratuity which gives them protection from uncertainties. They want to have participative management style; as none of us want to just follow the things but when we are involved, we feel a sense of responsibility. People want to be more versatile as monotonous work is not preferred anymore. Hence all these aspects are important and must be taken care to create perfect employer brand. Social media platforms are being used rampantly by many companies. Recruiter engagement through social media is still an area that needs to be explored and there is need to explore strategies that are going to work efficiently in this direction. Practitioners need to incorporate all the factors like psychological, economic and functional benefit in creating employer branding.

\section{Limitation of Study and Scope for Future Research}

One of the major limitations of our study is the number of respondents and the geographical reach. The sample size is acceptable but the number of focused group interview need to be increased. Respondents need to be selected from different geographical region to get a better concrete and diverse opinion. A further study is needed to be conducted to explore the interrelationship between social platform and creating employer brand and there is a need to work on developing strategy that can help to attract best talent. 


\section{Conclusion}

Organization's image perception and attractiveness do influence the job seekers to apply for the job. Employer branding is a sum of psychological, economic and functional benefits provided by employment and identified by the employer. It has a psychological impact on prospective employee. Value propositions are considered as a backbone of employer branding as it develops a clear vision about the organization and significantly helps in employee attraction and retention. This research paper explored the importance of employer branding and its impact on recruitment process. From this study, our findings suggest that social value is a very crucial value for employees or hiring a new employee in the organization. It is noticeable that jobseekers are giving more preference in the social values. While searching a job they give more preference to the employer-employee relations, good relations with colleague so that they can feel the sense of belongingness with the organization. Findings of the study will help the recruiters to adapt to better measures.

\section{References}

1. Armstrong, M. (2007). Employee Reward Management and Practice. London: Kogan Page Limited.

2. Ambler, T. \& Barrow, S. (1996), "The employer brand", The Journal of Brand Management, Vol. 4No. 3. 1996, pp. 185-206.

3. American Marketing Association (1960). Marketing Definitions: A Glossary of Marketing Terms, Chicago, American Marketing Association.

4. Arachchige, B.J.H. \& Robertson, A. (2011), "Business Students Perception of a Preferred Employer: A Study Identifying Determinants of Employer Branding", The IUP Journal of Brand Management, Vol.8, No.3, 2011, pp. 25-56

5. Backhaus, K., \& Tikoo, S. (2004). "Conceptualizing and researching employer branding." Career Development International. Vol. 9 No. 5, 2004, pp. 501-517, DOI 10.1108/13620430410550754

6. Berthon, P., Ewing, M. and Hah, L.L. (2005), "Captivating company: dimensions of attractiveness in employer branding", International Journal of Advertising, Vol. 24

7. Brown, Gordon (1992). People, Brands and Advertising. Warwick UK. Millward Brown International.

8. Burton, L.J. \& Mazerolle, S.M. (2011). "Survey Instrument Validity Part 1: Principles of Survey Instrument Development and Validation in Athletic Training Education Research". Atheletic Training Education Journal 6(1); 27-35.

9. Cable, D.M., \& Turban, D.B. (2003). The value of organizational reputation in the recruitment context: a brand-equity perspective. Journal of Applied Social Psychology, 33(11), 2244-2266.

10. Cable, D.M. and Judge, T.A. (1996), "Person-organization fit, job choice decisions and organizational entry", Organizational Behavior and Human Decision Processes, Vol. 43, pp. 294-311.

11. Cable, D. B. and Turban D. M. (2001), "Establishing the Dimensions, Sources and Value of Job Seekers' Employer Knowledge during Recruitment", Research in Personnel and Human Resource Management, Vol. 20, pp. 115-163. 
12. Cappelli, P. (2001), "Making the most of on-line recruiting", Harvard Business Review, March.

13. Cerny, C.A., \& Kaiser, H.F. (1977). A study of a measure of a sampling adequacy for factor-analytic correlation matrices. Multivariate Behavioral Research, 12(1), 43-47

14. Chhabra, N.L., \& Sharma, S. (2014). Employer branding: Strategy for improving employer attractiveness. International Journal of Organizational Analysis, 22(1), 48-60. Doi: 10.1108/IJOA-09-2011-0513.

15. Dabirian, A., Kietzmann, J., \& Diba, H., (2016), "A great place to work!? Understanding crowd sourced employer branding”, Kelley School of Business, Indiana University. Published by Elsevier Inc. http://dx.doi.org/10.1016/j.bushor.2016.11.005.

16. Edwards, M.R. (2010). "An integrative review of employer branding and OB theory", Personnel Review. Vol. 39 No. 1, 2010, pp. 5-23. DOI $10.1108 / 00483481011012809$

17. Fombrun, C.J. (1996) "Reputation: Realising Value from the Corporate Image" Harvard Business, School Press, Boston, MA.

18. Foster, C. Punjaisri, K. \& Cheng, R. (2010). "Exploring the relationship between corporate, internal and employer branding", Journal of Product \& Brand $\begin{array}{lllll}\text { Management } \quad \text { Vol. 19, No. 6(2010). Pp.401-409. DOI } & \text { D. }\end{array}$ 10.1108/10610421011085712]

19. Guthridge, M., Komm, A.B. and Lawson, E. (2008). Making talent a strategic priority. McKinsey Quarterly, 1, pp. 49-59.

20. Hadi, N.U. and Ahmed, S., (2018), "Role of Employer Branding Dimensions on Employee Retention: Evidence from Educational Sector", Administrative Sciences. 2018, Vol.8, issue. 44.DOI10.3390/admsci8030044.x

21. Kaiser, H.F. (1974). An index of factor simplicity. Psychometrika 39: 31-36.

22. Kapferer, J.N. (2004). The New Strategic Brand Management: Creating and Sustaining Brand Equity Long Term. London: Kogan Page.

23. Lievens, F., \& Highhouse, S. (2003). The Relation of Instrumental and Symbolic Attributes to a Company's Attractiveness as an Employer. Personnel Psychology, 56(1), 75-102.

24. Lievens, F., Van Hoye, G., \& Anseel, F. (2007). Organizational identity and employer image: towards a unifying framework. British Journal of Management, 18, S1, S45-S59

25. Lloyd, S. (2002). Branding from the inside out. Business Review Weekly, 24(10), 64-66. https://www.mediaguru.cz/clanky/2017/02/milenialove-venuji-25-casuprohlizeni-webu/

26. Micki, M. \& Micudova, K. (2018), "Employer Brand Building: using Social media and Career Websites to attract Generation Y". Economic and Sociology, 11(3), 171-189. DOI: :10.14254/2071-789X.2018/11-3/11

27. Mosley, R. W. 2007. Customer experience, organizational culture and the employer brand. Journal of Brand Management 15: 123-34. No. 2, pp. 151-172. http://dx.doi.org/10.1080/02650487.2005.11072912.

28. Riston. 2002. Impact of Employer Branding on Employee Attraction and Retention. European Journal on Business and Management 4: 2222-839. 
29. Schneider, B. (1987), "The people make the place", Personnel Psychology, Vol. 40 No. 3, pp. 437-454.

30. Sivertzen, A., Nilsen, E. R., \& olafsen, A. H., (2013), "Employer branding: Employer attractiveness and the use of social media". Journal of Product \& Brand management Vol.22, No.7. 2013, pp.473-483. DOI 10.1108/JPBM-092013-0393.

31. Srivastava, P, and Bhatnagar, J. (2010). Employer brand for talent acquisition: An exploration towards its measurement. The Journal of Business Perspective 14: 25-34.

32. Sullivan, John. 2004. Eight Elements of a Successful Employment Brand. ER Daily. February 23. Available online:

33. Swystun, J. (2007), "The brand glossary", Interbrand, Palgrave Macmillan, New York, NY.

34. Tabachnick, B.G. \& Fidell, L.S. (2001). Using multivariate Statistics. Needham Heights, M.A, Allyn \& Bacon.

35. Van Riel, C. B., \& Balmer, J. M. T. 1997. Corporate identity: The concept, its measurement, and management. European Journal of Marketing, 31, pp. 341355.

36. Wright, P.M., McMahan, G.C. and McWilliams, A. (1994), "Human resources and sustained competitive advantage: a resource-based perspective", International Journal of Management, Vol. 5 No. 2, pp. 301-326.

37. Xie, C., Bagozzi, R. and Meland, K. (2015), "The impact of reputation and identity congruence on employer brand attractiveness", Marketing Intelligence \& Planning, Vol. 33 No. 2, pp. 124-146. https://doi.org/10.1108/MIP-03-20140051

\section{About our Authors}

Puja Kumari is currently pursuing her doctoral research on e-recruitment trends in India. She has contributed several papers in reputed national and international management journals. She has also presented papers in national level conferences. She has attended several seminars, workshops and conferences related to Human resource issues in management, entrepreneurship, research methodology

Mili Dutta possesses 13 years of experience in academics and research. She is currently working as Assistant Professor, Department of Management, Birla Institute of Technology, Mesra, off-campus Lalpur, Ranchi. Her areas of interest include HR issues. She has contributed several papers in national and international management journals. She has also presented papers in national and international conferences. As a part of pursuit for academic excellence, she has attended several seminars, workshops and conferences related to strategic management, marketing research and teaching methodology.

Manju Bhagat is professor of Management at Birla Institute of Technology, Mesra. She has over 30 years of experience in academics and research. Apart from her doctoral research, she has contributed to research through several research papers and conference proceedings. She has guided several doctoral research students also. 
She has organized and mentored several seminars, workshops, conferences and management programs. Her areas of interest include labour economics and human relations, organization Behavior and industrial relation issues. She has also served as Head of the Department of Management. 